\title{
Empirical Study on Relations between Organizational Justice, Employees affection and Organization Performance
}

\author{
Maishou Li \\ School of Economics \\ Henan University \\ Kaifeng, China \\ E-mail:1ms@henu.edu.cn
}

\begin{abstract}
Sense of justice is an important psychological cognitive variable. Employee affection included in the employee competency is the key factor influencing the overall competitiveness of company. The goal of organization is to seek for high performance level. The objective of this article is to assess correlations between organizational Justice, employees affection and organization performance. Based on the literature review on organizational Justice, employees' affection and organization performance, conceptual model is structured. Then, Reliability analysis is applied to check the consistency and dimensionality of the scale items. Multiple regression analysis is also performed to check relations of three models. We find that organization justice has significant effect and prediction function on employee affection and organization performance. Moreover, employee affection plays the part moderating role, which means that the improvement of organization justice can promote the affection between employees and organization performance.
\end{abstract}

Keywords-organization justice; employee affection; organization performance

\section{INTRODUCTION}

Confronting complicated business environment, organization as the fundamental unit needs to sustain high creativity and cohesion. If the organization isn't fair and employees are lack of motivation, their affection and sense of accomplishment will be negatively affected. Since equity theory is initiated by J.S. Adams, research on organizational justice has 30 years of history and the research achievement is fruitful. Equity theory describes that employees will compare their own input and output with those of others, which focuses on the research of the rationality and fairness of pay distribution. Sense of fairness will directly influence employee work motivation and behavior [1]. When employees feel they are treated unfairly, they will take the following six measures, which are to change input, change output, change their own cognitive, refuse to exchange opinions for others and select another different referents and to quit the job [2]. Moreover, Equity theory as one of the basic theory of motivation not only correlates with relations between superior and subordinates, overall work atmosphere, team cohesion, organization performance and enterprise sustainability, but also directly or indirectly affects employee behavior, satisfaction and conscientiousness, thereby organization performance will also be affected [3].

Research on human relation in organization behavior mainly concentrates on the view of conflict. Traditional view holds that conflict mainly results from factors such as poor communication and being lack of trust and honesty [4]. There is still controversy on whether conflict has positive or negative effect on organization performance. Human relations scholar identifies that conflict is unavoidable and conflict can be accepted and become reasonable. Interaction scholar thinks the conflict style will determine whether conflict has positive or negative effect on organization performance.

\section{THEORETICAL FOUNDATION AND HYPOTHESIS}

Early equity mainly focuses on the fairness of pay distribution and its effect on employee output [5]. Thibaut proposed the concept of procedure justice through the research of different judicial procedure towards the extent of result satisfaction, which consists of controlling procedure and decision procedure [6].Some scholars also propose different dimensions of equity. For example, interactive equity theory started by Bies emphasizes the interaction and communication fairness between superiority and personnel. Greenberg proposes the concept of interpersonal justice and information justice. Interpersonal justice emphasizes that employees can obtain fair personal treatment in the process of communication. In addition, information justice focuses of the channel of the available information [7]. Liuya (2003) finds that organization justice has significantly positive correlation with organization commitment, subjective performance, satisfaction, citizenship behavior and turnover intention through exploring the effect of organization justice on variables of organization effectiveness, which also has strong predictability [8].Wang Xinyan (2009) concludes that for the organization justice structure under Chinese background, interactive justice is the most important that can facilitate employee performance, organization commitment and organization citizenship behavior [9]. It's obvious that 
no matter the performance or the organization will result in the high sense of accomplishments. Therefore, organization justice has positive effect on employees' sense of accomplishment.

The concept of employees' affection is similar to that of human relationship, affection and organization climate. Employee affection mainly refers to the cognitive perception on justice, support, human relationship and employee status approval. Scholars at aboard empirically find that employees' turnover intention and satisfaction with job correlates highly with organization affection, which can have effect on the employee perception of work environment and job satisfaction description. Research on employee affection mainly focuses on individual emotion character, which generally believes can be divided into positive emotion and negative emotion [10]. Zhaoyong (2006) describes that in a certain compensation range, compensation satisfaction level with highly active affection is greater than that of the low active level [11]. However, when the compensation level is extremely low, compensation satisfaction level with active affection is less than that of the low level [12]. Individual affection will influence job satisfaction and happiness [13]. Besides, good organization climate can significantly facilitate company innovation, organization change and team invisible knowledge sharing.

Referring to Macduffie (1995), organization financial performance is measured by profit growth ratio and sales growth ratio [14]. Moreover, according to the research by Huselid (2003), human resource performance is measured by employee satisfaction, employee production ration, employee turnover ration and individual performance [15].

Based on the above analysis, four hypotheses are proposed and the conceptual model shown in "Fig. 1" between organization justice, employee affection and organization performance is structured.

$\mathrm{H} 1$ : organization justice has significant positive effect on organization performance.

$\mathrm{H} 2$ : organization justice has significant positive effect on employee affection.

H3: employee affection has significant positive effect on organization performance.

H4: employee affection and organization justice play the moderating role in organization performance.

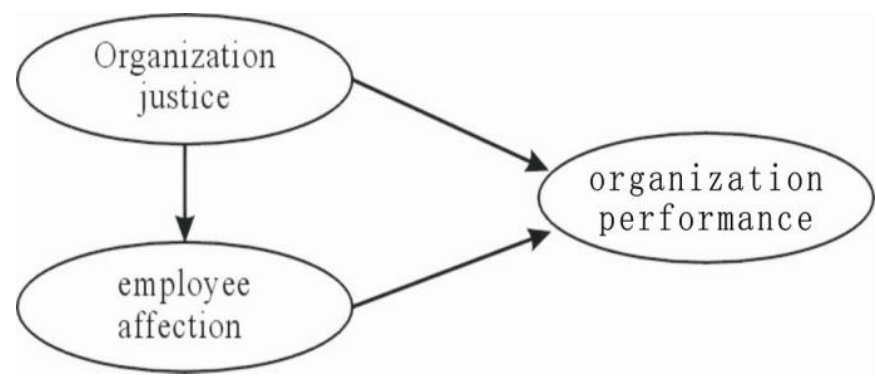

Fig. 1. Conceptual model

\section{DeSIGN AND MethodologiES}

\section{A. Sample Design}

The sampling frame consisted of governmental units, scientific research institutes, finance and manufacturing industries to complete questionnaires by posting, E-mail and visiting. Data collection yielded 800 questionnaires. After dropping surveys completed by individuals not fully answered or given invalid answers, a useable sample of 639 questionnaires was utilized in this study (valid response rate $88.62 \%$ ). Sample collection can be seen in "Table I" .

TABLE I. SAMPLE DISTRIBUTION

\begin{tabular}{|c|c|c|c|}
\hline $\begin{array}{l}\text { Statistical } \\
\text { item }\end{array}$ & sample situation & $\begin{array}{c}\text { Sample } \\
\text { amount } \\
(639)\end{array}$ & percentage \\
\hline \multirow[t]{2}{*}{ gender } & male & 341 & $53.4 \%$ \\
\hline & female & 298 & $44.6 \%$ \\
\hline \multirow{4}{*}{$\begin{array}{l}\text { organizatio } \\
\mathrm{n} \text { style }\end{array}$} & government units & 134 & $21 \%$ \\
\hline & $\begin{array}{l}\text { scientific research } \\
\text { institute }\end{array}$ & 168 & $26.3 \%$ \\
\hline & Finance industry & 238 & $37.2 \%$ \\
\hline & Manufacturing industry & 99 & $15.5 \%$ \\
\hline \multirow{5}{*}{$\begin{array}{l}\text { age } \\
\text { structure }\end{array}$} & Below 20 years & 2 & $0.3 \%$ \\
\hline & 21-30 years & 335 & $52.4 \%$ \\
\hline & $31-40$ years & 214 & $33.5 \%$ \\
\hline & $41-50$ years & 79 & $12.4 \%$ \\
\hline & 51years above & 9 & $1.4 \%$ \\
\hline \multirow{5}{*}{$\begin{array}{l}\text { qualificatio } \\
\text { n structure }\end{array}$} & High school or below & 38 & $5.9 \%$ \\
\hline & Diploma degree & 139 & $21.8 \%$ \\
\hline & Bachelor degree & 345 & $54.0 \%$ \\
\hline & Master degree & 103 & $16.1 \%$ \\
\hline & Doctor degree & 14 & $2.2 \%$ \\
\hline
\end{tabular}

This sample questionnaire consists of 18 questions, with each 6 questions for organization justice, employee affection and organization performance. 7 rank score is used to evaluate statements using 7 for mostly matched and 1 for strongly unmatched. Organization justice questions refer to the scale designed by Niehoff. Employee affection and organization performance question mainly refer to the scale designed by David Sirota. Employee affection scale is measured through colleague collaboration, communication, reasonable competition and harmonious human relations. Organization performance is measured by six factors, which are the accomplishment of challenging work, new skill obtaining, execution power and the realization of job importance, appreciation of performance and proud feeling of job. Cronbachs Alpha of each scale is 0.879, 0.883 and 0.915. According to the view of Bryman and Cramer, the sample has good validity with the Cronbach Alpha being 0.8 or above, shown in "Table II". 
TABLE II. TEST SCALE

\begin{tabular}{|c|c|c|c|}
\hline Scale & Items & KMO & $\mathrm{a}$ \\
\hline \multirow{6}{*}{$\begin{array}{l}\text { Organization } \\
\text { Justice }\end{array}$} & A1 compared with similar job, pay is very competitive. & \multirow[t]{6}{*}{0.831} & \multirow[t]{6}{*}{0.879} \\
\hline & A2 benefit is above the average level, compared with similar job. & & \\
\hline & A3 Superiority treat subordinates respectfully and approachably. & & \\
\hline & A4 Superiority can provide satisfactory work condition. & & \\
\hline & A5 my reward is appropriate with my qualification. & & \\
\hline & A6 I am treated fairly in my company. & & \\
\hline \multirow[t]{6}{*}{$\begin{array}{l}\text { Employee } \\
\text { affection }\end{array}$} & $\begin{array}{l}\text { B1 company encourages cooperation between individual and team and Employees are always taking the } \\
\text { responsibility. }\end{array}$ & \multirow[t]{6}{*}{0.883} & \multirow[t]{6}{*}{0.883} \\
\hline & B2 organization is always encouraging communication. & & \\
\hline & B3 competition between colleagues is virtuous and good for organization development. & & \\
\hline & B4 you and your colleague are closely connected. & & \\
\hline & B5 you and your colleague are always cooperating well. Conflict can be solved together. & & \\
\hline & B6 Climate of study is strong between colleagues. you appreciate and learn with each other, & & \\
\hline \multirow{6}{*}{$\begin{array}{l}\text { Organization } \\
\text { performance }\end{array}$} & C1 organization can provide potential promotion opportunity for employees & \multirow[t]{6}{*}{0.896} & \multirow[t]{6}{*}{0.915} \\
\hline & C2 superior reasonably inspects employees. Initiative is the key for subordinates to accomplish jobs. & & \\
\hline & C3superior can widely appreciate employees and continuously motive the potential capability of employees & & \\
\hline & C4superior is always attempting to communicate with subordinates and encouraging employees' participation. & & \\
\hline & C5 Superior encourages subordinates to totally engage in overall work. & & \\
\hline & C6 your current job content can continuously motivate your enthusiasm on job. & & \\
\hline
\end{tabular}

\section{B. Empirical Analysis Result}

Organization justice scale extracts one common factor, the eign value of which is 3.762 and explained variable is $62.7 \%$. Employee affection scale extracts one factor, the eign value of which is 3.809 and explained variable is $63.489 \%$.Organization peformance scale and organization justice scale extract one common factor, the characteristic value of which is 4.227 and explained variable is $70.458 \%$.It's turned out that these three scales are in accordance with the nature of one dimension measuring tool. In addition, Pearson correlation coefficient under each item and each scale at the level of 0.01 is significantly correlated, which can explain that validity of sample structure is quite good and less information is lost. We can find Pearson correlation coefficient under each item and scale in "Table III", "Table IV" and "Table V".

Because sample of organization justice, employee affection and organization performance has high reliability and validity and can satisfy the need of standard variable treatment, mean calculation is applied. "Table VI" indicates the correlation coefficient, mean and variance of each variable. Industry character correlates highly with employee affection and organization performance. Gender correlates negatively with employee accomplishment at the level of 0.05 . Age correlates negatively with organization justice and organization performance at the level of 0.05 . Moreover, years of enrollment correlates negatively with all three variables and qualification correlates with organization justice significantly at the level of 0.05 .
TABLE III. PEARSONS' COEFFICIENT AND FACTOR LOADING FOR EACH ITEM UNDER ORGANIZATION JUSTICE SCALE

\begin{tabular}{|c|c|c|c|c|c|c|}
\hline & $\mathbf{A 1}$ & $\mathbf{A 2}$ & $\mathbf{A 3}$ & $\mathbf{A 4}$ & $\mathbf{A 5}$ & $\begin{array}{c}\text { factor } \\
\text { loading }\end{array}$ \\
\hline $\mathbf{A 1}$ & - & & & & & 0.771 \\
\hline $\mathbf{A 2}$ & $0.743^{* *}$ & - & & & & 0.774 \\
\hline $\mathbf{A 3}$ & $0.422^{* *}$ & $0.465^{* *}$ & - & & & 0.770 \\
\hline $\mathbf{A 4}$ & $0.411^{* *}$ & $0.423^{* *}$ & $0.667^{* *}$ & - & & 0.773 \\
\hline $\mathbf{A 5}$ & $0.568^{* *}$ & $0.537^{* *}$ & $0.527^{* *}$ & $0.607 * *$ & - & 0.832 \\
\hline $\mathbf{A 6}$ & $0.531^{* *}$ & $0.525^{* *}$ & $0.588^{* *}$ & $0.572^{* *}$ & $0.689^{* *}$ & 0.827 \\
\hline
\end{tabular}

${ }^{\text {a. }}$ Note ; ***indicates significant corre lation at 0.001 level; $* *$ indicates significant corre lation at 0.01 level; *indicates significant correlation at 0.05 le vel

TABLE IV. PEARSONS' COEFFICIENT FOR EACH ITEM UNDER EMPLOYEE AFFECTION SCALE

\begin{tabular}{|c|c|c|c|c|c|c|}
\hline & B1 & B2 & B3 & B4 & B5 & $\begin{array}{c}\text { factor } \\
\text { loading }\end{array}$ \\
\hline B1 & - & & & & & 0.812 \\
\hline B2 & $0.627^{* *}$ & - & & & & 0.780 \\
\hline B3 & $0.591^{* *}$ & $0.571^{* *}$ & - & & & 0.787 \\
\hline B4 & $0.501^{*} *$ & $0.491 * *$ & $0.475^{* *}$ & - & & 0.751 \\
\hline B5 & $0.543^{*} *$ & $0.534 * *$ & $0.582^{* *}$ & $0.595^{* *}$ & - & 0.828 \\
\hline B6 & $0.609^{* *}$ & $0.514^{* *}$ & $0.545^{* *}$ & $0.554^{* *}$ & $0.685^{* *}$ & 0.812 \\
\hline
\end{tabular}

${ }^{\mathrm{b} .}$ Note ; $* * *$ indicates significant corre lation at 0.001 level; $* *$ indicates significant correlation at 0.01 level; *indicates significant corre lation at 0.05 level.

TABLE V. PEARSONS' COEFFICIENT FOR EACH ITEM UNDER ORGANIZATION PERFORMANCE SCALE

\begin{tabular}{|c|c|c|c|c|c|c|}
\hline & C1 & C2 & C3 & C4 & C5 & $\begin{array}{c}\text { factor } \\
\text { loading }\end{array}$ \\
\hline C1 & - & & & & & 0.844 \\
\hline C2 & $0.598^{* *}$ & - & & & & 0.759 \\
\hline C3 & $0.684^{* *}$ & $0.628^{* *}$ & - & & & 0.853 \\
\hline C4 & $0.655^{* *}$ & $0.567^{* *}$ & $0.724^{* *}$ & - & & 0.870 \\
\hline C5 & $0.627^{* *}$ & $0.546^{* *}$ & $0.618^{* *}$ & $0.726^{* *}$ & - & 0.850 \\
\hline C6 & $0.684^{* *}$ & $0.531^{* *}$ & $0.638^{* *}$ & $0.689^{* *}$ & $0.747^{* *}$ & 0.855 \\
\hline
\end{tabular}

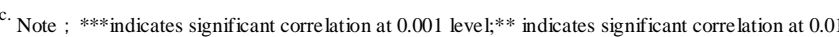
level; *indicates significant correlation at 0.05 level. 
TABLE VI. DESCRIPTIVE STATISTICAL ANALYSIS OF VARIABLES AND MATRIX OF COEFFICIENT

\begin{tabular}{|c|c|c|c|c|c|c|c|c|}
\hline Variable & $\mathbf{1}$ & 2 & 3 & 4 & 5 & 6 & 7 & 8 \\
\hline Industry character & - & & & & & & & \\
\hline Gender & 0.045 & - & & & & & & \\
\hline Age & 0.005 & $--0.117 * *$ & - & & & & & \\
\hline Enrollment duration & 0.045 & --0.009 & $0.695 * *$ & - & & & & \\
\hline Qualification & $--0.382 * *$ & $--0.189 * *$ & $--0.182 * *$ & $--0.283^{* *}$ & - & & & \\
\hline Organization justice & 0.070 & --0.068 & $--0.087 *$ & $--0.262^{* *}$ & $0.009^{*}$ & - & & \\
\hline Affection between colleagues & $0.108^{* *}$ & --0.018 & --0.072 & $--0.222 * *$ & 0.061 & $0.715^{* *}$ & - & \\
\hline Organization performance & $0.105^{* *}$ & $--0.093 * *$ & $--0.081^{*}$ & $--0.254 * *$ & 0.062 & $0.779 * *$ & $0.767 * *$ & \\
\hline Mean & 2.47 & 1.47 & 2.62 & 2.55 & 2.87 & 4.60 & 5.08 & 4.92 \\
\hline SD & 0.99 & 0.50 & 0.76 & 1.26 & 0.83 & 1.12 & 1.00 & 1.16 \\
\hline
\end{tabular}

${ }^{\text {d. }}$ Note ; ***indicates significant correlation at 0.001 level; $* *$ indicates significant correlation at 0.01 level; $*$ indicates significant corre lation at 0.05 le vel.

Proposed hypothesis is tested by hierarchical regression model. Firstly, industry character, gender, age, enrollment duration and qualification are defined as controllable variable and model 1 is obtained to take employee affection as dependent variable. Secondly, based on model 1, organization justice as independent variable is added based on model 1. Thirdly, organization performance is taken as dependent variable and industry character, gender, age, enrollment duration and qualification as controllable variable to get model 2. Fourthly, organization justice as independent variable adds to mode 13 and model 4 is obtained. Lastly, organization justice and employee affection add to model 4 and model 5 is obtained. According to the test result, model
2 and model 4 indicate that organization justice has significant positive correlation with employee affection seen in model $2\left(\beta=0.698^{* * *}, \quad \mathrm{P}=0.000\right)$ and organization performance seen in model $4(\beta=0.754 * * *, \quad \mathrm{P}=0.000)$. Therefore, hypothesis 1 and hypothesis 2 are tested. Furthermore, in model $5\left(\beta=0.426^{* * *}, \mathrm{P}=0.000\right)$ it's turned out that employee affection correlates significantly with organization performance. Therefore, hypothesis 3 is verified. Seen from model 4 and model 5, when employee affection is introduced, influence coefficient of organization justice on performance reduces from 0.754 to 0.456 , which proves that employee affection plays part moderating role. Therefore, hypothesis 4 is tested. "Table VII"

TABLE VII. MEdiating EFFECT OF EMPLOYeE AfFeCtion TeSt

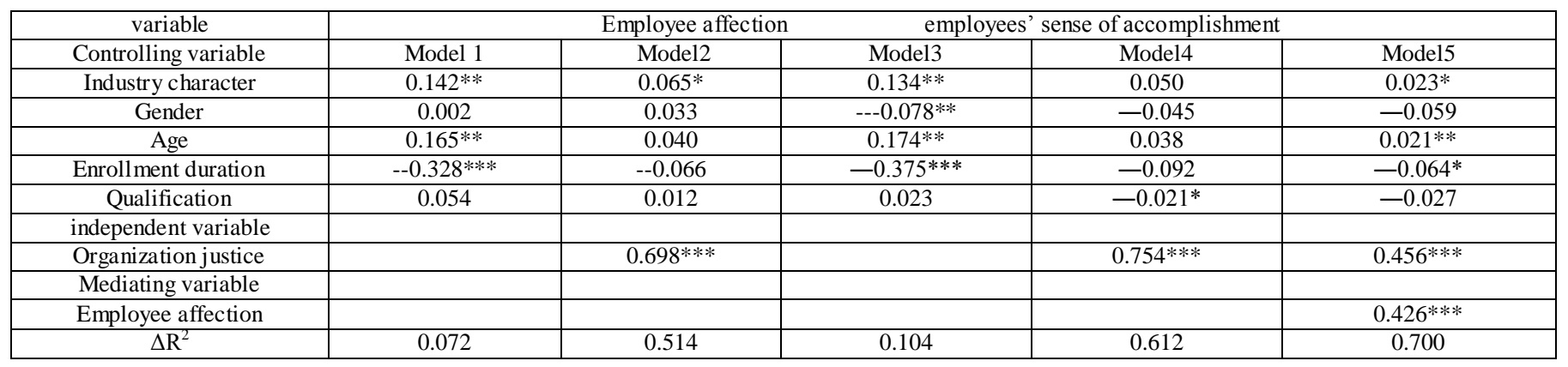

e. Note ; $* * *$ indicates significant corre lation at 0.001 level;;* indicates significant correlation at 0.01 level;; $*$ indicates significant corre lation at 0.05 level.

Next, linear regression analysis is applied to determine each path coefficient for model without controlled variable. Based on the model, there are two paths which are effect of organization justice and employee affection on organization performance and the effect of organization justice on employee affection. According to "Table VIII", employee perception and employee affection play different roles in employees' sense of accomplishment. Organization justice is the most important, which has significant effect on organization performance and employee affection. However, employee affection has similar effect on organization performance and organization justice "Fig. 2".

TABLE VIII. MOdEL Path PaRAMETERS AND Relative STATISTICS

\begin{tabular}{|l|l|c|c|c|c|c|c|}
\hline \multicolumn{1}{|c|}{$\begin{array}{c}\text { Dependent } \\
\text { variable }\end{array}$} & \multicolumn{1}{|c|}{$\begin{array}{c}\text { Independent } \\
\text { variable }\end{array}$} & $\mathbf{\beta}$ & $\mathbf{t}$ & $\mathbf{p}$ & $\mathbf{F}$ & $\mathbf{R}^{2}$ & Adjusted R $^{2}$ \\
\hline $\begin{array}{l}\text { Organization } \\
\text { performance }\end{array}$ & Organization justice & 0.471 & 15.091 & 0.000 & 731.627 & 0.697 & 0.696 \\
\cline { 2 - 6 } & Employee affection & 0.430 & 13.758 & 0.000 & & & \\
\hline Employee affection & $\begin{array}{l}\text { Perceived justice of } \\
\text { employee }\end{array}$ & 0.641 & 25.84 & 0.000 & 668.197 & 0.512 & 0.511 \\
\hline
\end{tabular}




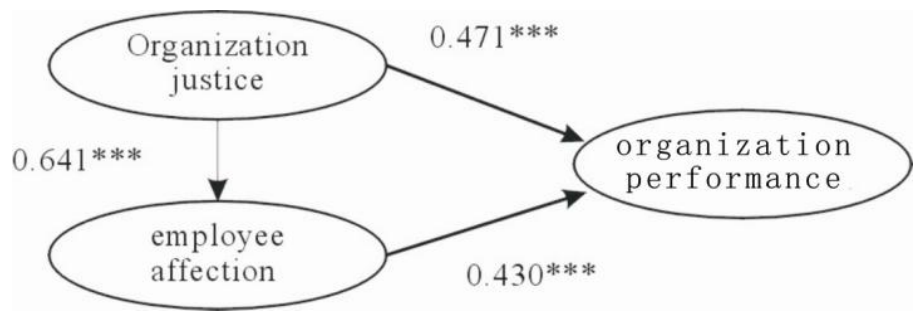

Fig. 2. Model Path Parameter

\section{CONCLUSION}

From the empirical study result, it's concluded that organization justice has significant effect and prediction function on employee affection and organization performance, which means the execution of organization justice can help predict employees' affection and organization performance. Moreover, employee affection plays the part moderating role, which means that the improvement of organization justice can promote the affection between employees and organization.

The research result is of great value for business management practice in China. From the theoretical view, organization justice belongs to equity theory. However, employee affection belongs to hierarchical needs theory. The theoretical value focuses on the proof of both two motivation theory that's the equity theory and hierarchical theory are not separated with each other but interacts with each other and they have internal conformity. For business practice, organization justice system must be built and structured, such as ensuring distribution justice by reasonable approach, interaction between superiority and subordinates and fair channel for information available. Since the reform and open policy is executed, the absolutely fair distribution system has been broken. But the recent distribution model seems to go for another extreme. Gap between different industry and position is great, which hurts employees' motivation and organization performance. Therefore, fair environment is especially important to be built, which can not only improve employee affection but also enhance employees' sense of accomplishment and royalty. Next, it's important to manage affection, which in essence, is people first policy and the coordinated development of fully respect individual goals and organization objective. Affection management not only emphasizes emotions between leaders and employees but also the inner team members and external emotion, which is in accordance with the reality of human sympathy and human relations. Emotion communication can help improve the feeling of the identity and responsibility of taking company as home. Thereby, great cohesion could be formed to promote organization performance. Communication platform can be constructed to strengthen employee affection and perception of organization identity to finally enhance employees' sense of accomplishment.

\section{REFERENCES}

[1] Sheldon Alexander and Marian Ruderman. "The Role of Procedural and Distributive Justice in Organizational Behavior", Social Justice Research, vol.1., no.2.pp177-198,1987.

[2] Rusell E Johnson,Christopher Selenta and Robert G Lord. "When Organizational Justice and the Self-concept Meet:Consequences for the Organization and Its Memebers",Organization Behaviol and Human Decision Process,vol.99,no.2,pp175-201.,2006.

[3] Fuyang,Feiwang and Xingmin Cao, "Effect of Compensation justice on Employees' Responsibility", Science and Scientific Study Management,vol3,pp.173-178.,2010.

[4] Steven.P.Robinson, Organization Behavior [M].People's University of China. Beijing, pp177-179., 1998.

[5] Dean B McFarlin, Paul D Sweeney. "Distributive and Procedural Justice as Predictors of Satisfaction with Personal and Organizational Outcomes", The Academy of Management Journal, vol. 35.,no. 3.,pp.626-637.1992.

[6] Greenberg J. "The Social Side of Fairness: Interpersonal and Informational Classes of Organizational Justice”,Hillsdale,1993.

[7] Linda Musantle,Marcia A Gillbert and John Thibaut. "The Effects of Control on Perceived Fairness of Procedures and Outcomes",Journal of Experimental Social Psychology,vol19.no.3,pp.223-238.,1983.

[8] Liuya,Longli Rong andYe Hua, "Impact of Organization justice on Organization Outcome”.Management World,vol3,pp.126-132.,2003.

[9] Xinyan wang, "Empirical Analysis on the Structure and Current Situation of Organization justice",Management Review,vol9.pp.3947.2009.

[10] Schimmack U,Oishi S,RSHkeiahnn P,"Culture, Personality and Subjective Well-Being: Integrating Process Models of Life Satisfaction", Journal of Personality and Social Psychology,vol84.no.4.,pp582-592.

[11] Yongzhao, Yezheng Liu and Sunyang, "Study on Relations of Positive Affection, Negative Affection and Compensation Satisfactory", Science and Scientific Study Management,vol.7.pp152-156.2006.

[12] David Sirota, "Motivating Employees----Gaining Profit Through Meeting the Key Needs of Employees"[M]. People's University of China. Beijing.

[13] Zhu Yingjun, "The Impact of Performance Appraisal Orientation on Information Ethics Behavior of Public Servant", JDCTA, Vol. 5, No. 5, pp. $279 \sim 284,2011$

[14] Macduffie J P,1995.Human Resource Bundles and Manufacturing Performance: Organizational Logic and Flexible Production Systems in the World Auto Industry .Industrial and Labor Relations Review, 48: 197-221.

[15] Huselid M A.2003, The Impact of Human Resource Management Practices on Turnover, Productivity , and Corporate Financial Performance, Academy of Management Journal,.38:635-672. 